\title{
Trends in U.S. Sweet Orange, Grapefruit, and Mandarin-type Cultivars
}

\author{
Ed Stover ${ }^{1}$, William Castle ${ }^{2}$, and Chih-Cheng T. Chao ${ }^{3}$
}

AdDitionAl INDEX WORDs. citrus, grapefruit, juice, mandarin, orange, processing

SumMARY. The world market for citrus (Citrus spp.) products has undergone dramatic shifts over the last decade. These shifts are influencing development and planting of new citrus cultivars. Seedlessness and very easy peeling have become paramount in mandarin types (C. reticulata and hybrids), and new cultivars are being developed through plant breeding and selection of new sports. In both sweet orange (C. sinensis) and grapefruit (C. paradisi), essentially all important cultivars are derived from a single original hybrid of each fruit type, and plant improvement has focused on selection of sports with redder color and extended maturity. The existence of many active citrus breeding programs makes it likely that we will continue to see evolution of new citrus cultivars over the foreseeable future.

\section{Introduction to the origin of citrus cultivars}

$\mathrm{T}$ The genus Citrusis comprised of numerous genotypes producing a wildly divergent array of fruits. Only the genus Prunus, source of almond (P.dulcis), apricot (P.armeniaca), sweet cherry (P. avium), sour cherry (P.cerasus), peaches/nectarines ( $P$. persica), and plums ( $P$. domestica, $P$. cerasifera, P. salicina, and hybrids) can begin to compete for the sheer variety of fruit crops found within a single genus. Citrus displays a strong tendency for apomixis. Many genotypes form numerous embryos per seed, with most genetically identical to the mother tree. This has had a profound influence on the development of cultivars and even apparent species (Hodgson, 1967). Numerical taxonomic evaluation suggested that three "true" species are primary contributors to the amazing array of distinctive commercial citrus types that we now know (Barrett and Rhodes, 1976; Scora, 1975), and this notion has been supported by recent molecular studies (Moore, 2001; Nicolosi et al., 2000). These species are $C$. reticulata (the mandarins), C. maxima [the pummelos (formerly known as $C$.

${ }^{1}$ Indian River Research \& Education Center, University of Florida, Ft. Pierce, FL 34945; current address USDA/ARS, National Clonal Germplasm Repository, One Shields Avenue, Davis, CA 95616

${ }^{2}$ University of Florida, Citrus Research and Education Center, 700 Experiment Station Rd., Lake Alfred, FL 33850.

${ }^{3}$ Department of Botany and Plant Sciences, University of California-Riverside, Riverside, CA 92521

Florida Agricultural Experiment Station Journal Series No. R-10819. grandis)], and C.medica (the citrons), with various obscure species making more minor contributions (Nicolosi et al., 2000). Most commercial citrus types are believed to have originated in the region from Southeast Asia through northeastern India (Hodgson, 1967). The evolution of citrus appears to be the result of hybridization between these progenitor species, subsequent hybridization and rehybridization between progenitor species and previously derived hybrids, fixation of identifiable types through apomixis, and derivation of sports (either budsports or sports derived from apomictic embryos) to yield diversity within apomictic "species" (Fig. 1). For easy reference, the cultivars mentioned in this paper are listed in Table 1.

\section{Market demands}

For commercial producers, serious discussion of cultivars should occur within the context of market demands and trends. The world market for citrus products has undergone dramatic shifts over the last decade. Increased global trade in fruits has provided many consumers with opportunities to buy almost any fruit year-round. Thus, fresh citrus no longer dominates winter fruit sales. Also, several other trends affect the attractiveness of fresh citrus fruit.

Consumers appear to be less willing to spend time preparing fruit for

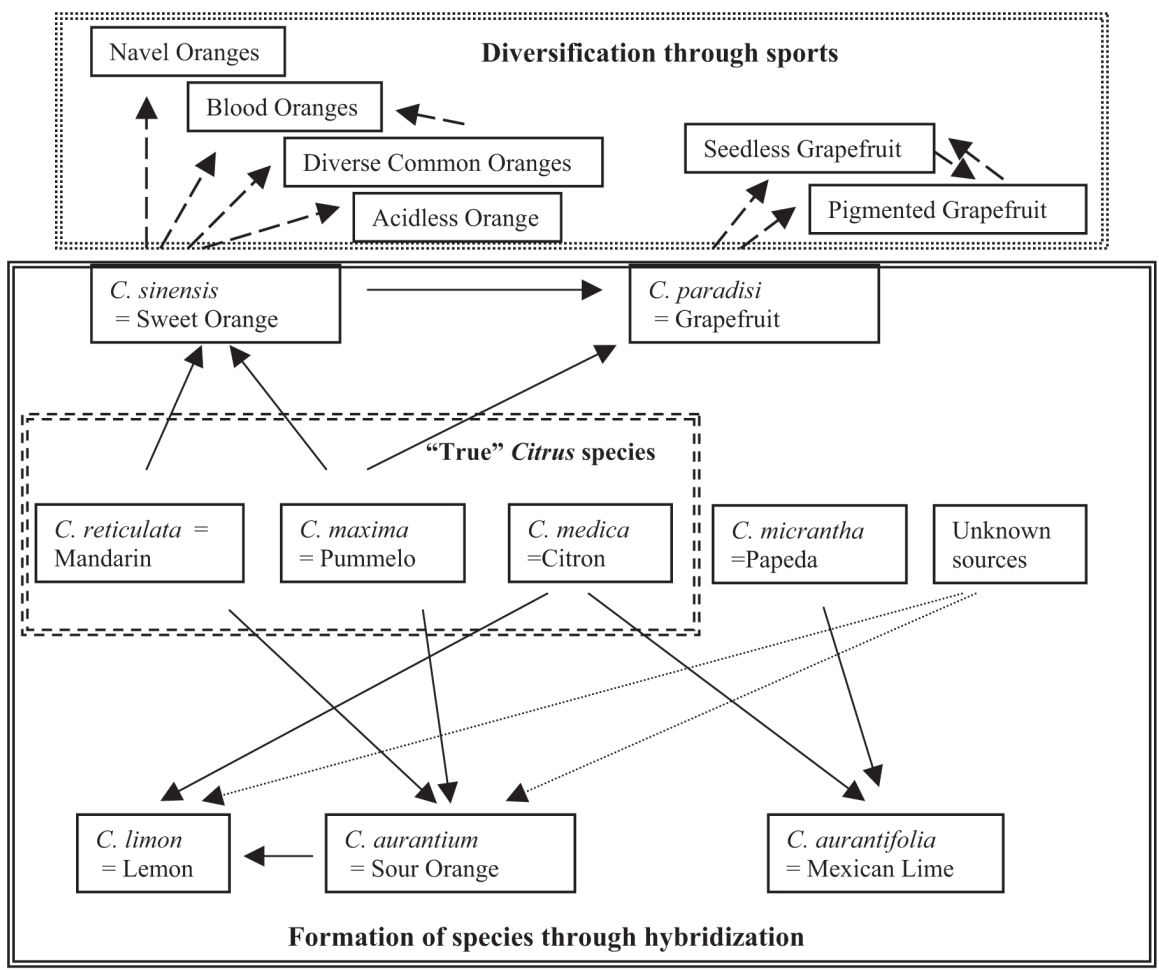

Fig. 1. Deduced origins of many major citrus cultivar types of commerce: three "true" species of citrus hybridized with some contribution of other sources to produce "hybrid" species that have been sustained through apomixis and vegetative propagation. Relationships expressed in the figure are based on molecular marker data presented by Nicolosi et al. (2000). Diverse cultivars of sweet orange and grapefruit have developed from presumed original hybrids through sports. 
Table 1. Citrus cultivars discussed in this review of trends in U.S. sweet orange, grapefruit, and mandarin-type cultivars.

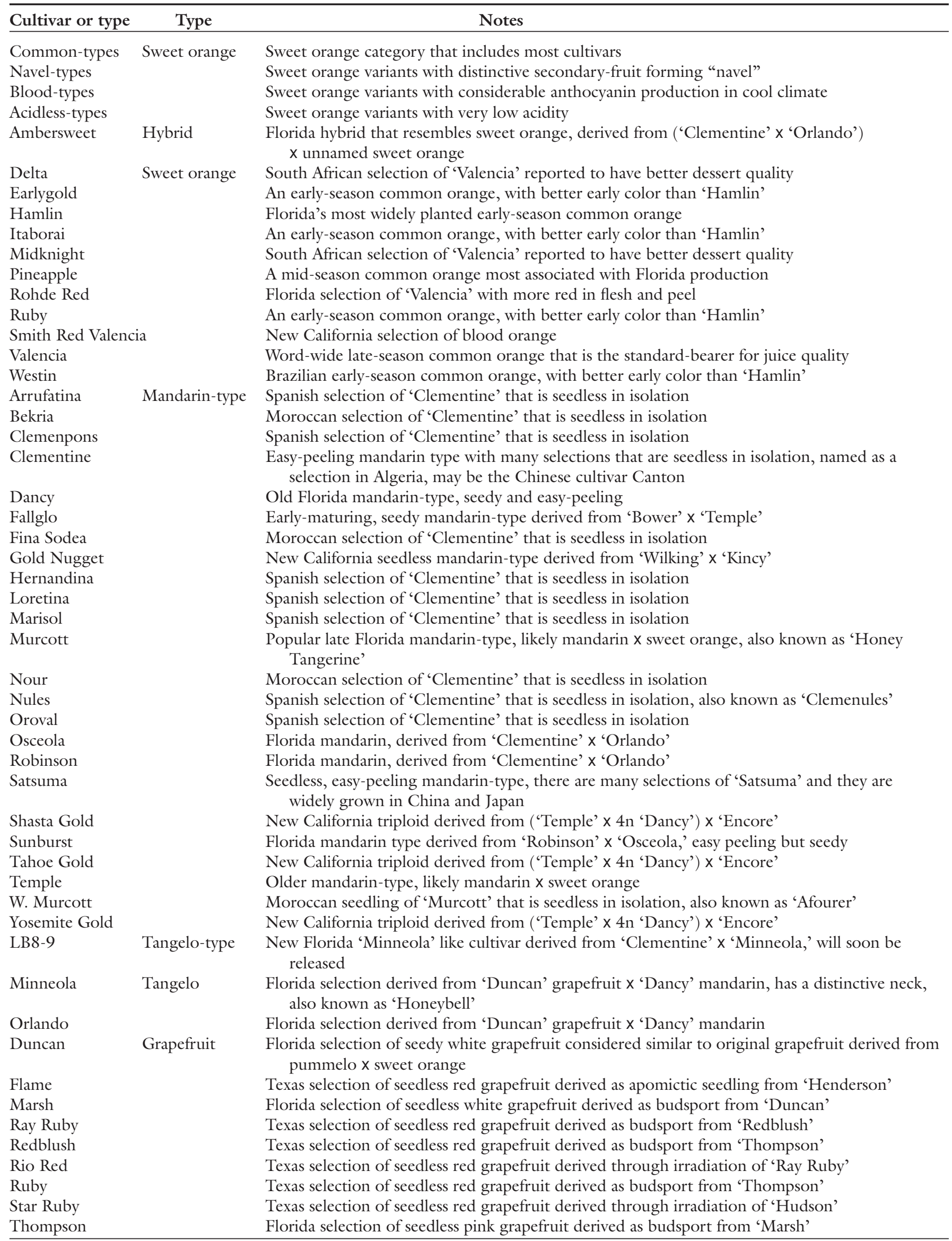


consumption (i.e., peeling, slicing, removing seeds, etc.), but are willing to spend more for ready-to-eat (i.e., "fresh-cut") products (Ragaert et al., 2004). U.S. consumers often want fruit they can eat while driving in their cars! U.S. residents consume $19 \%$ of their meals in cars, according to research by J. Nihoff(Lednicer, 2003), a professor at the Culinary Institute of America. One in five Canadians also eats breakfast "on the go" (Ipsos-Reid, 2003).

Florida fresh citrus producers are feeling these changes. Returns are dwindling for delicious but seedy and hard-to-peel mandarin types, and are often very low for navel oranges and grapefruit (Florida citrus growers, personal communications). The high juice content that characterizes Florida citrus may be a detriment for eating fruit out of hand. Grapefruit sales are suffering the additional blow of warnings against consumption with many medications (Associated Press, 2001). The risk of drug interactions with grapefruit may be exaggerated (Associated Press, 2001), but debate continues.

The world fresh citrus industry is experiencing substantial movement toward very-easy-peeling seedless mandarins, most notably 'Clementine' (Brown and Brown, 2001). Sweet oranges continue to be the largest category of dessert citrus sold worldwide $(\sim 55 \%)$ and grapefruit still make up about $10 \%$ of world fresh citrus sales, but mandarins and hybrids now account for $30 \%$ of sales (Florida Department of Citrus, 2003) and likely a much higher percentage of world profits on fresh citrus. In California, 'Valencia' plantings are being removed at a rapid rate and orchards of seedless mandarins are often springing up in their place The bearing acreage of Valencia decreased from 65,000 to 60,000 acres $(26,305$ to 24,281 ha) in 2002 in California, while California mandarin production increased by $27 \%$ from 2002 to 2003 (National Agricultural Statistics Service, 2004). Paralleling this trend toward very-easy peelers, the market for small volumes of very-high-quality specialty fruits remains strong, but there are some risks: 1) failure to attract consumer interest; and 2 ) overproduction, which drives down prices.

The processed citrus market is also responding to shifting consumer demand. Fresh-cut citrus products (Del
Monte, 2001) and other minimally processed products, such as frozen juice vesicles, are being explored to increase utilization and consumer demand for fresh citrus. Not-from-concentrate and reconstituted juice now dominate the U.S. market (Brown and Brown, 2001). The not-from-concentrate market has increased demand for high soluble solids and high-color early oranges, and efforts continue to expand the harvest period for top-quality juice 'Valencia'.

Pome and stone fruit producers have entered an era in which the most popular new cultivars provide tremendous returns to growers while established commodity cultivars often provide returns near production costs. In personal conversations, apple (Malus $\times$ domestica) growers in western Europe and New Zealand have indicated that orchard commercial life may only be 10-12 years because of a constant demand for newer cultivars. The New Zealand apple industry plans to capitalize on this trend by introducing a new cultivar every 2 years (DeMarree, 2003) and substantial acreage is planted to yet unnamed cultivars. With several active citrus breeding programs around the world, we may soon see the same strategy in citrus production.

\section{Sweet orange cultivars}

Sweet orange remains the most widely grown citrus fruit in the world. Florida produces about $80 \%$ of U.S. sweet oranges with $95 \%$ used for processing (Florida Department of Citrus, 2003) while most of the remaining U.S. production is used fresh. Sweet orange cultivars can be categorized into four distinct groups: common oranges (also known as blond oranges in Europe and round oranges in Florida), navel oranges, blood oranges, and acidless oranges (Hodgson, 1967). These distinctive types appear to have arisen through successive mutations derived from a single original sweet orange (Fang and Roose, 1997), which was likely a pummelo $\mathrm{x}$ mandarin hybrid (Nicolosi et al., 2000). In Florida, most oranges of economic importance are common oranges, such as the familiar 'Hamlin', 'Pineapple', and 'Valencia'. While 'Valencia' is the most important single cultivar worldwide, navel types are widely considered the preeminent dessert orange (Saunt, 1990). Navel oranges are characterized by a small, secondary fruit embedded in the stylar end of the primary fruit.

Blood oranges have distinctive red flesh and often peel coloration from anthocyanin pigments, and are primarily grown in western Mediterranean countries (Saunt, 1990). Red pigmentation is enhanced by cool temperatures, and distinctive bloodorange color is undeveloped in Florida and other warm climate citrus regions, but their flavor, often described as raspberry-like, can be present. The acidless oranges are very low in acid with a very sweet, but insipid flavor to many palates. Although grown for local consumption in Mediterranean regions, Egypt, Spain, Brazil and Mexico, they are of minor importance in most citrus-producing regions (Williamson and Jackson, 1993).

'Valencia' is the leading cultivar of sweet orange in both Florida and the world. The juice color and quality are the standards of excellence by which other sweet orange cultivars are judged. Fruit store exceptionally well on the tree but may re-green during late spring or early summer. Just as existing cultivars appear to be mutants of the original sweet orange (Fang and Roose, 1997), new cultivars continue to arise through identification of desirable mutations. For example, 'Rohde Red' Valencia is a Florida selection with better juice color (Rouse, 2000). 'Delta' and 'Midknight' are recent late-season selections of South African origin with better dessert fruit quality (Tribulato et al., 2001). Efforts are under way to accelerate generation of mutations in sweet orange and to select strains with improved fruit quality or altered maturation in somaclonal variants derived from tissue culture (Grosser et al., 2000).

Several other sweet orange cultivars, with early juice color superior to the standard 'Hamlin', interesting flavor, and/or good soluble solids, have become routinely planted in Florida over the last few years (Castle and Ferguson, 2003). Interest in these cultivars, such as 'Earlygold', 'Itaborai', 'Ruby', and 'Westin', has been triggered by the rise in importance of not-from-concentrate juice, since early maturing, high quality juice oranges reduce the duration and volume of 'Valencia' juice that must be stored during the summer and fall. Bureau of Citrus Budwood Registration (2002) records indicate that about 1.6 million trees of these selections were propagated 
from 1999 through 2002. The most popular selection has been 'Earlygold' ( $59 \%$ of the total), followed by 'Westin', 'Itaborai', and 'Ruby'.

Because sweet orange is grown so extensively around the world, many sports will continue to be found. The most recent named sport is 'Smith Red Valencia', a blood orange identified in California after a homeowner repeatedly called the extension agent to complain that a neighbor was injecting her fruit with blood (L. Ferguson, personal communication).

Only one sweet orange type has clearly arisen from controlled hybridization: 'Ambersweet', released by the USDA in 1989 by C.J. Hearn. It is a hybrid of 'Clementine' mandarin by 'Orlando' tangelo (grapefruit $x$ mandarin hybrid) crossed with a seedling mid-season sweet orange. 'Ambersweet' is an early-season cultivar with good juice color and a distinctive flavor when mature. It is somewhat earlier than navel and was widely planted in Florida after its release. However, poor production (Albrigo et al., 2001) and low juice content have largely eliminated this cultivar from commercial production in Florida.

\section{Grapefruit cultivars}

Grapefruit cultivars have also arisen through mutations from a single original grapefruit genotype. Grapefruit were first reported growing in Barbados about 1750, where they were known as "forbidden fruit". Since that time, the development of all commercially significant cultivars through bud sports is well documented (Gmitter, 1995). Molecular marker evaluations are consistent with the reported origin of grapefruit cultivars through mutation (Fang and Roose, 1997), and the first grapefruit was probably a pummelo $\mathrm{X}$ sweet orange hybrid (Nicolosi et al., 2000).

The original grapefruit was very seedy and yellowish-white fleshed, and likely very similar to the cultivar Duncan. Seedy cultivars quickly went out of demand following the discovery of the seedless 'Marsh' (also known as 'Marsh Seedless', still the most widely planted grapefruit in the world (Williamson, 1997), and subsequent cultivar releases have focused on increasingly red flesh and peel. Color intensity increases in the progression of 'Thompson' (or 'Pink Marsh', a limb sport of 'Marsh'), 'Redblush' and 'Ruby' (both believed to be limb sports of 'Thompson'), and 'Ray Ruby' (found in a 'Redblush' grove) (Williamson, 1997). Similarly, the deep-red 'Flame' cultivar is a spontaneous mutation following a different succession of cultivars from 'Marsh' (Saunt, 1990). Texas A\&M University has developed several deep red grapefruit cultivars through use of irradiation to accelerate mutation. 'Star Ruby' and 'Rio Red' were both identified following gamma irradiation of budwood (Saunt, 1990). Even redder sports, some with distinctive flavor characteristics, continue to be found in the block where 'Rio Red' was found. Remarkable new cultivars will most likely be released from this program (E. Louzada, personal communication). New grapefruit cultivars may also emerge from somaclonal variants derived from tissue culture (Grosser et al., 2000).

\section{Mandarin-type cultivars}

Unlike sweet oranges and grapefruit, many cultivars of mandarin-type fruit have been developed through hybridization. 'Sunburst', a 'Robinson' $x$ 'Osceola' hybrid, is the most widely grown commercial early mandarin type in Florida. 'Sunburst' fruit are a beautiful deep orange color and have a delicious flavor, require pollenization for good fruit set and generally average between 10 to 20 seeds per fruit (Futch and Jackson, 2003a). 'Murcott' (also called 'Honey Tangerine'), likely a cross between a mandarin and a sweet orange, is grown globally and is the most widely grown late mandarin type in Florida. As with 'Sunburst', the color and flavor are exceptional but fruit tend to be quite seedy, but 'Murcott' is self-compatible (Futch and Jackson, 2003b). The citrus hybrid 'Fallglo' is the result of a 1962 cross between 'Bower' and 'Temple'. 'Fallglo' is marketed before 'Sunburst' is ready in Florida, is very seedy, and has a history of postharvest problems related to degreening (Futch and Jackson, 2003c). Profitability of these seedy cultivars has been wildly variable and appears to be threatened by production of seedless mandarin types.

'Satsuma' mandarins are easy peeling and seedless even when planted with diverse cultivars that may provide viable pollen. The citrus industries of both China and Japan heavily emphasize 'Satsuma'. Selection of slight mutations and seedlings has resulted in over 100 satsuma cultivars that differ in date of maturity, fruit shape, color, and quality (Ferguson, 1996). Outside of Japan, 'Satsuma' mandarins are a minor but sometimes important part of the cultivar mix. In warmer regions like much of Florida, they lose acidity quickly and have a brief window of market suitability. They are very prone to puffing, and postharvest quality has been less consistent than the 'Clementine' described below. However, 'Satsuma' is unique as a very-easy peeler that does not require isolation from other pollen to remain seedless. For this reason, there are California trials with 'Satsuma' selections in an effort to identify superior genotypes. Interestingly, some of these selections have distinctive flavors or have early maturity that may provide additional marketing opportunities.

There are two stories about the origin of 'Clementine', the first that it is a hybrid discovered by Father Clement in Algeria, and the second that it is a traditional cultivar grown in China (Saunt, 1990). This original 'Clementine' is a good but seedy mandarin. The major breakthrough of commercial significance was the discovery of 'Clementine' that was seedless when grown away from other effective pollen sources. Gibberellic acid should be applied after peak bloom to enhance set of parthenocarpic fruit for most 'Clementine'. Seedless 'Clementine' has become the darling of citrus regions that can produce it and the scourge of regions that cannot. At its best, seedless 'Clementine' offers the consumer a very-easy-peeling fruit, with no seeds, and no release of juice when the sections are separated: the perfect citrus to eat while driving. It also has very satisfactory postharvest performance. Spain has been at the forefront of developing seedless 'Clementine' through selection of sports and refining of production techniques. Seedless cultivars include 'Arrufatina', 'Clemenpons', 'Fina Sodea', 'Hernandina', 'Loretina', 'Marisol', 'Nules' (sometimes called 'Clemenules'), and 'Oroval' (Saunt, 1990), and new cultivars seem to be introduced on a routine basis . 'Bekria' and 'Nour' are two seedless 'Clementines' identified in Morocco. Production of seedless 'Clementine' appears to be much more difficult in the more stressful spring of Florida's subtropical climate than in Mediterranean climates. 'Clemen- 
tine' is now being actively planted in California.

A new cultivar has arisen which may complement and sometimes challenge 'Clementine'. 'W. Murcott' ( synonym = 'Afourer') reportedly arose as a seedling from an open-pollinated 'Murcott' tree in Morocco. The fruit are similar in size and shape to 'Murcott', but have the important advantage of being seedless when grown in isolation from compatible pollenizers (Castle et al., 2004; Chao et al., 2005). 'W. Murcott' is being widely planted in Morocco and California and is commanding excellent market acceptance and price as a similar product to 'Clementine', with a peak maturity later than 'Clementine' but somewhat overlapping in season. In an ongoing California trial, 'W. Murcott' outproduced 'Clementine' and 'Satsuma' (Ferguson et al., 2000). 'W. Murcott' trees have consistently been very productive when young, with little evidence of alternate bearing (C.T. Chao, unpublished data). If grown in solid blocks away from other cultivars with compatible pollen, 'W. Murcott' will set seedless fruit in Florida, but consistent production of commercial crops has not been demonstrated (Castle et al., 2004). Some California seedless 'W. Murcott' fruit are being marketed under the trade name Delite (Mulholland Citrus, Orange Cove, Calif.).

Dr. Mikeal Roose at the University of California-Riverside has been very active in developing new mandarintype cultivars. 'Gold Nugget' is a seedless mandarin hybrid recently released from this program in 1999 (Roose et al., 1999). It is late season, extremely tasty, but has a rough skin. 'Tahoe Gold', 'Shasta Gold', and 'Yosemite Gold' were released from this program in 2003. They are all triploid hybrids of ('Temple' unreduced gamete $x 4 n$ 'Dancy') $x$ 'Encore'. All three cultivars are large fruited, seedless, with a rich sweet flavor and a tendency to alternate bear. They are not as easypeeling as 'Clementine', 'W. Murcott', or 'Satsuma'.

An important subset of the mandarin-type citrus is the tangelos. 'Minneola' is a 'Duncan' grapefruit $x$ 'Dancy' mandarin hybrid released in 1931. The fruit is attractive and delicious to eat. Most 'Minneola' fruit are characterized by a stem-end neck that tends to make the fruit appear pear or bell-shaped. This appearance has given rise to the name "Honeybell" in the gift fruit trade (Jackson and Futch, 2003). It is the antithesis of a convenience fruit, hard to peel with abundant release of juice when handling (some Florida growers call it a "sink orange" because it is so juicy you need to eat it over the sink), but prices remain excellent for 'Minneola'. In this case, the low productivity of 'Minneola' and its extreme susceptibility to the fungal disease alternaria (Alternaria alternata) make it difficult to overproduce.

'LB8-9' is a 'Clementine' $x$ 'Minneola' hybrid from F.G. Gmitter's program at the University of Florida. It produces a fruit and tree similar to 'Minneola' but trees bear more heavily, and this new hybrid shows limited susceptibility to alternaria. It may be slightly earlier than 'Minneola' and could permit a Thanksgiving market. Fruit are seedy and tend to be smaller than 'Minneola'. It is expected to be released soon, officially for "dooryard" use, and the name has not been determined.

Numerous seedless triploid mandarins from University of Florida breeding programs are under evaluation along with somaclonal variants of 'Valencia' and several grapefruit cultivars that vary in season of maturity and a few other characteristics. Along with more hybrids from traditional breeding, M.L. Roose from the University of California-Riverside is using irradiation to produce mandarin hybrids that are seedless even when good pollenizers are nearby. He has interesting selections of 'W. Murcott' and many other cultivars (M.L. Roose, personal communication). We are fortunate to have numerous active citrus breeding and evaluation programs. Doubtless, we will continue to see a parade of new cultivars throughout future years.

\section{Literature cited}

Albrigo, L.G., D.S. Achor, and R.V. Russ. 2001. Low production of Ambersweet orange in Florida related to poor pollen production and germination. Proc. Fla. Soc. Hort. Sci. 114:127-131.

Associated Press. 2001. Grapefruit industry tries to counter drug-interaction claims. 2 Dec. 2004. <http:// www.intelihealth.com/IH/ihtIH/WSIHW000/8124/21291/326035.html>.

Barrett, H.C. and A.M. Rhodes. 1976. A numerical taxonomic study of affinity rela- tionships in cultivated Citrus and its close relatives. Systematic Bot. 1:105-136.

Brown, C.A. and M.G. Brown. 2001. Florida citrus outlook. 3 Dec. 2004. <http://www.floridajuice.com/pdfs/ wp20011.pdf>.

Bureau of Citrus Budwood Registration. 2002. Annual report. 6 Dec. 2004. <http://doacs.state.fl.us/pi/budwood/ ar2002.html>.

Castle, B., T. Hammond, and M. Kesinger. 2004. W. Murcott: A new scion variety on the scene. Citrus Ind. Mag. 85(5):13-14.

Castle, W.S. and J.J. Ferguson. 2003. Earlymaturing sweet oranges: Research update on Earlygold, Itaborai, Ruby, and Westin sweet oranges. 6 Dec. 2004. <http://edis. ifas.ufl.edu/HS173>.

Chao, C.T., J. Fang, and P.S. Devanand. 2005. Long distance pollen flow in mandarin orchards determined by AFLP markers-Implication for seedless mandarin production. J. Amer. Soc. Hort. Sci. 130:374-380.

Del Monte. 2001. Del Monte fresh produce expands into fresh cut citrus with leading edge automation technology. 3 Dec. 2004. <http://www.corporate-ir.net/ireye/ ir_site .zhtml? ticker $=$ FDP\&script $=410 \&$ la yout $=0 \&$ item_id $=224115>$.

DeMarree, A. 2003. New Zealand strategies for competing in a global marketplace. 3 Dec. 2004. <http://www.nyfarmnet. org/services/publications/newzealand. htm>.

Fang, D.Q. and M.L. Roose. 1997. Identification of closely related citrus cultivars with inter-simple sequence repeat markers. Theoretical Appl. Genet. 95:408-417.

Ferguson, J.J. 1996. The Satsuma tangerine. 6 Dec. 2004. <http://edis.ifas.ufl. edu/CH1l6>.

Ferguson, L., M.L. Arpaia, T. Chao, H. Reyes, and P. Metheney. 2000. Current field evaluations of mandarin cultivars for California. 6 Dec. 2004. <http:// fruitsandnuts.ucdavis.edu/louise/Citrograph01.pdf>.

Florida Department of Citrus. 2003. Citrus reference book 2003. 3 Dec. 2004. <http://www.fred.ifas.ufl.edu/citrus/ pubs/ref/acre.htm\#t2l $>$.

Futch, S.H. and L.K. Jackson. 2003a. Sunburst tangerine. 6 Dec. 2004 . <http://edis. ifas.ufl.edu/CH079>.

Futch, S.H. and L.K. Jackson. 2003b. Murcott (Honey tangerine). 6 Dec. 2004 .<http://edis.ifas.ufl.edu/ $\mathrm{CH} 078>$. 
Futch, S.H. and L.K. Jackson. 2003c. Fallglo tangerine. 6 Dec. 2004. <http://edis. ifas.ufl.edu/CH075>.

Gmitter, F.G. 1995. Origin, evolution, and breeding of the grapefruit. Plant Breeding Rev. 13:345-363.

Grosser, J.W., F.G. Gmitter, Jr., G.H. Fleming, and J.L. Chandler. 2000. Applications of biotechnology to citrus cultivar improvement at the Citrus Research and Education Center. Acta Hort. 535:213-220.

Hodgson, R.W. 1967. Horticultural varieties of citrus, p. 431-591. In: W. Reuther, H.J. Webber, and L.D. Batchelor (eds.). The citrus industry, vol. 1. Univ. of California.

Ipsos-Reid. 2003. Six in ten Canadians report eating breakfast everyday. $6 \mathrm{Dec}$. 2004. <http://www.ipsos-na.com/news/ pressrelease.cfm?id=1831 $>$.

Jackson, L.K. and S.H. Futch. 2003. The Minneola tangelo. 6 Dec. 2004. <http:// edis.ifas.ufl.edu/CH072>

Lednicer, L.G. 2003. Drivers add new meaning to 'meals to go.' 13 Dec. 2004. $<$ http://www.itd.idaho.gov/transporter/2003/120503_Trans/120503_FoodToGo.html>.

Moore, G.A. 2001. Oranges and lemons: Clues to the taxonomy of Citrus from molecular markers. Trends Genet. 17:536-540.

National Agricultural Statistics Service. 2004. California agricultural statistics, 2003. 13 Dec. 2004. <ftp://www. nass.usda.gov/pub/nass/ca/AgStats / 2003cas-all.pdf>.
Nicolosi, E., Z.N. Deng, A. Gentile, S. La Malfa, G. Continella, and E. Tribulato. 2000. Citrus phylogeny and genetic origins of important species as investigated by molecular markers. Theoretical Appl. Genet. 100:1155-1166.

Ragaert, P., W. Verbeke, F. Devlieghere, and J. Debevere. 2004. Consumer perception and choice of minimally processed vegetables and packaged fruits. Food Quality Preference 15:259-270.

Roose, M.L., T.E.Williams, J.W. Cameron, and R.K. Soost. 1999. 'Gold Nugget' mandarin, a seedless, late-maturing hybrid. HortScience 35:1176-1178.

Rouse, R.E. 2000. Citrus fruit quality and yield of six Valencia clones on 16 rootstocks in the Immokalee Foundation Grove. Proc. Fla. Soc. Hort. Sci. 113:112-114.

Saunt, J. 1990. Citrus varieties of the world, an illustrated guide. 2 nd ed. Sinclair Intl., Norwich, U.K.

Scora, R.W. 1975. On the history and origin of Citrus. Bul. Torrey Bot. Club 102:369-375

Tribulato, E., G. la Rosa, and E. Nicolosi. 2001. New accessions of Valencia Late orange. Rivista di Frutticultura e di Ortofloricoltura 63:29-32.

Williamson, J.G. 1997. The grapefruit. 6 Dec. 2004.<http://edis.ifas.ufl.edu/ CH063>.

Williamson, J.G. and L.K. Jackson. 1993. Sweet orange. 6 Dec. 2004. <http://edis. ifas.ufl.edu/CH066>. 